\title{
Agrobacterium-mediated transformation of Amaranthus cruentus L. epicotyls by the ARGOS-LIKE transgene
} Taipova R.M. ${ }^{1}$, Kuluev B.R. ${ }^{1,2}$

${ }^{1}$ Bashkir State University, Ufa, Russia; ${ }^{2}$ Institute of Biochemistry and Genetics - Subdivision of the Ufa Federal Research Centre of the RAS, Ufa, Russia

E-mail: Taipova.Ragida@yandex.ru

Key message. The present study describes the results of our research in Agrobacterium-mediated transformation of epicotyl segments of Amaranthus cruentus variety "Bagryanyi” by the ARGOS-LIKE transgene of Arabidopsis thaliana controlled by the $35 S$ promoter. For shoot regeneration from epicotyl segments after Agrobacterium-mediated transformation, MurashigeSkoog (MS) medium containing $13 \mu M$ 6-benzylaminopurine and $1 \mu M \alpha$-naphthylacetic acid was used. For the selection of transgenic shoots, $10 \mathrm{mg} / \mathrm{L}$ of hygromycin $B$ was added to the MS medium.

Keywords: Amaranthus cruentus, Agrobacterium-mediated transformation, transgenic plants, ARGOS-LIKE, in vitro

Amaranthus cruentus L. is a valuable fodder and grain crop. To generate new varieties of this plant, genetic transformation methods can be used, but for A. cruentus such methods remain undeveloped. The purpose of the presented work was to develop a method for agrobacterium-mediated transformation of the cultural species of the A. cruentus using the genetic engineering structure 35S::ARGOS-LIKE (ARL), containing of Arabidopsis thaliana ARGOS-LIKE gene, encoding one of the negative regulators of ethylene signaling. Segments of cotyledons, hypocotyles and epicotyles (explants) were cut out of seven-day seedlings in sterile conditions and cultured for 6 days on a regenerative MS medium containing $13 \mu \mathrm{M} 6$ benzylaminopurine and $1 \mu \mathrm{M} \alpha$-naphthylacetic acid. Then the segments previously subjected to injury were immersed in a bacterial suspension for 10 minutes, after which they were slightly dried with sterile filter paper and transferred to the same regeneration medium for co-cultivation with agrobacteria. Joint cultivation of explants with agrobacterium was carried out for 2 days, after which they were washed with antibiotic solution of cefotaxime $(300 \mathrm{mg} / \mathrm{l})$ and were transferred to selective MS medium with the same growth regulators (BAP and NAA) with similar concentrations and antibiotics with cefotaxime 300 $\mathrm{mg} / \mathrm{l}$ and hygromycin B (10 mg/L). Explants, which on selective medium started regenerating shoots were replanted on MS medium with $2 \mu \mathrm{M}$ BAP, $2 \mu \mathrm{M}$ 3-indoleacetic acid (IAA) and hygromycin B $(10 \mathrm{mg} / \mathrm{l})$. From amaranth plants rooted in a selective environment and acclimated to soil conditions, DNA was isolated by salt extraction and the resulting samples were subjected to PCR analysis for the presence of the target ARL gene and marker genes for $\beta$-glucuronidase (GUS) and hygromycin phosphotransferase (HPT).

Three transgenic amaranth plants with the genetic engineering structure 35S::ARL were generated. The efficiency of Agrobacterium-mediated transformation of A. cruentus was 4\%. Two transgenic plants were acclimatized to soil and open air conditions.

\section{Агробактериальная трансформация эксплантов эпикотилей амаранта багряного Amaranthus cruentus L. трансгеном ARGOS-LIKE}

Таипова Р.М. ${ }^{1}$, Кулуев Б.P. ${ }^{1,2}$

${ }^{1}$ Башкирский государственный университет, Уфа, Россия; ${ }^{2}$ Институт биохимии и генетики - обособленное структурное подразделение Федерального государственного бюджетного научного учреждения Уфимского федерального исследовательского центра Российской академии наук, Уфа, Россия

\begin{abstract}
Аннотация. Описаны результаты агробактериальной трансформации сегментов эпикотилей A. cruеnthиs сорта «Багряный» трансгеном ARGOS-LIKE Arabidopsis thaliana L., находящимся под контролем 35S промотора. Для регенерации побегов из сегментов эпикотилей после агробактериальной трансформации использовали среду Мурасиге-Скуга, содержашую 13 мкМ 6-бензиламинопурина и 1 мкМ $\alpha$-нафтилуксусной кислоты.
\end{abstract}

Ключевые слова: Amaranthus cruеntus, агробактериальная трансформация, трансгенные растения, ARGOS-LIKE, in vitro

Амарант багряный Amaranthus cruentus L. является ценной кормовой и зерновой культурой. Для получения новых сортов этого растения могут быть использованы методы генетической трансформации, однако для A. cruentus такие технологии остаются неразработанными. Целью представленной работы была разработка метода агробактериальной трансформации культурного вида амаранта багряного A. cruentus с использованием генно-инженерной конструкции $35 S: \because A R G O S-L I K E$ (ARL). В работе использовали генно-инженерную конструкцию $35 S:: A R L$, содержащую целевой ген ARGOS-LIKE из A. thaliana, кодирующий один из негативных регуляторов этиленового сигналинга. Из семидневных проростков в стерильных условиях вырезали сегменты семядольных листьев, гипокотилей и эпикотилей (экспланты) и культивировали в течение 6 суток на регенерационной среде МС, содержащей 13 мкМ 6-бензиламинопурина (БАП) и 1 мкМ $\alpha$-нафтилуксусной кислоты (НУК). Затем сегменты, предварительно подвергнутые поранению, погружали в агробактериальную суспензию на 10 минут, после чего немного подсушивали стерильной фильтровальной бумагой и переносили на такую же регенерационную среду для сокультивации с агробактериями. Совместное культивирование эксплантов с агробактериями проводили в течение 2 суток, по истечении которых их промывали раствором антибиотика цефотаксима (300 мг/л) и переносили на селективную среду МС с теми же регуляторами роста (БАП и НУК) с аналогичными концентрациями и антибиотиками цефотаксимом - 300 мг/л и гигромицином В (10 мг/л). Экспланты, на которых на селективной среде начинали регенерировать побеги, пересаживали на среду МС с 2 мкМ БАП, 2 мкМ 3-индолилуксусной кислоты (ИУК) и гигромицином В (10 мг/л). Из укоренившихся на селективной среде и акклиматизированных к условиям почвы растений амаранта выделяли ДНК методом солевой экстракции и полученные образцы подвергали ПЦР-анализу на присутствие целевого гена $A R L$ и маркерных генов, кодирующих $\beta$-глюкуронидазу $(G U S)$ и гигромицинфосфотрансферазу $(H P T)$.

В ходе проведенной работы были получены 3 трансгенных растения амаранта багряного, несущие генно-инженерную конструкцию $35 S:: A R L$. Процент эффективности агробактериальной трансформации A. cruentus при использованном нами методе составил 4\%. Два трансгенных растения удалось акклиматизировать к условиям почвы и открытого грунта. 